Old Dominion University

ODU Digital Commons

Philosophy Faculty Publications

Philosophy \& Religious Studies

2018

Nietzsche on Loneliness, Self-Transformation, and the Eternal

Recurrence

Justin Remhof

Old Dominion University, jremhof@odu.edu

Follow this and additional works at: https://digitalcommons.odu.edu/philosophy_fac_pubs

Part of the Continental Philosophy Commons, and the Philosophy of Mind Commons

Original Publication Citation

Remhof, J. (2018). Nietzsche on loneliness, self-transformation, and the eternal recurrence. Journal of Nietzsche Studies, 49(2), 194-213. https://doi.org/10.5325/jnietstud.49.2.0194

This Article is brought to you for free and open access by the Philosophy \& Religious Studies at ODU Digital Commons. It has been accepted for inclusion in Philosophy Faculty Publications by an authorized administrator of ODU Digital Commons. For more information, please contact digitalcommons@odu.edu. 


\section{PROJECT MUSE}

Nietzsche on Loneliness, Self-Transformation, and the

\section{Eternal Recurrence}

Justin Remhof

The Journal of Nietzsche Studies, Volume 49, Issue 2, Autumn 2018, pp. 194-213 (Article)

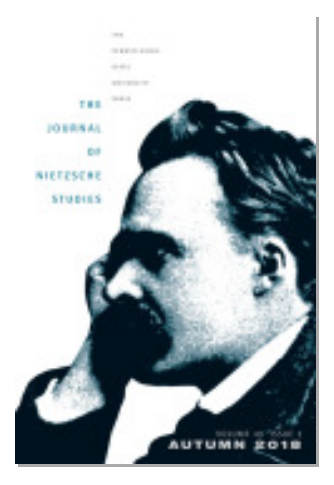

Published by Penn State University Press

$\Rightarrow$ For additional information about this article https://muse.jhu.edu/article/711020 


\title{
Nietzsche on Loneliness, Self-Transformation, and the Eternal Recurrence
}

\author{
JUSTIN REMHOF | OLD DOMINION UNIVERSITY
}

\begin{abstract}
Nietzsche's presentation of the eternal recurrence in Gay Science 341 is often viewed as a practical thought experiment meant to radically transform us. But exactly why and how we are supposed to be transformed is not clear. I contend that addressing these issues requires taking a close look at the psychological setting of the passage. The eternal recurrence is presented in our "loneliest loneliness." I argue that facing the eternal recurrence from a state of profound loneliness both motivates self-transformation and contributes toward helping us succeed at that project.
\end{abstract}

Keywords: loneliness, eternal recurrence, self-transformation, morality, empirical psychology

What Cara would forget is that talking to her sister, Cara didn't feel any of those things. That for a time she only felt lonely: a loneliness so physical it was part of her, a second tongue that shaped her every word, a muscle so strong and necessary she was certain it had always been there.

-Kevin Clouther, "Puritan Hotel, Boston"

Nietzsche's presentation of the eternal recurrence in $G S_{341}$ is often viewed as a practical thought experiment aimed at testing the worth of a life, rather than a metaphysical view about the way the world is. ${ }^{1}$ The experiment concerns a "demon" who tells us "this life as you now live it and have lived it you will have to live once again and innumerable times again" (GS 341). ${ }^{2}$ This thought is supposed to radically transform us. Nietzsche states, "If this thought gained power over you, as you are it would transform and possibly crush you" (GS 341). ${ }^{3}$ And, at the end of the passage, he asks, "how well 
disposed would you have to become to yourself and to life to long for nothing more fervently than for this ultimate eternal confirmation and seal?" (GS 341). But exactly why and how we are supposed to be transformed is not clear. I contend that addressing these issues requires taking a close look at something that has received very little attention in the literature: the fact that the demon presents the eternal recurrence in our "loneliest loneliness [einsamste Einsamkeit]." In this article, I aim to explain why and how Nietzsche thinks facing the eternal recurrence in a psychological state of our deepest loneliness is supposed to be transformative.

Here is the plan. I begin by explaining why "Einsamkeit" should be translated as "loneliness" and offering a basic definition of loneliness. Afterward I describe the reaction that Nietzsche anticipates our having when we imagine the eternal recurrence in a state of severe loneliness: out of horror, we want to reject the demon's suggestion. But loneliness, I argue, motivates its own overcoming, like hunger or thirst. I then point to contemporary empirical psychological research to suggest that loneliness both motivates Nietzschean self-transformation and supplies crucial conditions that help enable success. Such success empowers us to affirm the eternal recurrence. I finish by responding to objections, explaining an important virtue of my account, and showing that other interpretations of the psychological setting of the test fail to secure the motivation to undergo and achieve Nietzschean self-transformation.

Let us begin. My reading of the eternal recurrence in GS 341 turns on translating "Einsamkeit" as "loneliness." But "Einsamkeit" could also be rendered as "solitude," in which case "einsamste Einsamkeit" would be "most solitary solitude." ${ }^{5}$ How should we pick a translation? We should prefer whatever best fits Nietzsche's aims. "Loneliness" best satisfies the aim of GS 341, which is to provoke self-transformation. Nietzsche regards solitude as a virtue that indicates confident self-reliance. Those who are "higher" and "greater," he says, including "free spirits" and "philosophers of the future," are "friends of solitude" (BGE 44; see also EH P 3). Loneliness indicates something else entirely. Nietzsche connects loneliness with "shades of distress," "weariness," and "gloominess" (BGE 26; see also Z III: "The Wanderer"). Loneliness involves vulnerability. We are vulnerable when lonely because we feel that something about our lives is missing or unfulfilled. Specifically, we are precluded from making certain connections that we long to establish, connections that concern who we take ourselves to be. ${ }^{6}$ Such feelings can push us to transform our lives. Indeed, Nietzsche 
tends to believe that the best forms of change come from suffering. ${ }^{7}$ Confident self-reliance seems to have no such motivational force. When translating "Einsamkeit" in GS 341, then, we have reason to prefer "loneliness" over "solitude," and this translation choice will gain further support as we continue. ${ }^{8}$

What does "loneliness" mean? Ordinarily, it signifies the pain of feeling alone. Depending on the individual and circumstance, of course, loneliness can mean much more. For instance, it can indicate a painful sense of longing or loss of support. Loneliness could point to something fleeting, maybe even momentarily welcomed, or it could signify an enduring sense of desolation, perhaps even inconsolable loss. Despite such nuances, understanding loneliness merely as the pain of feeling alone will suffice for the argument I develop below. ${ }^{9}$ Importantly, by linking loneliness with "shades of distress," "weariness," and "gloominess" (BGE 26), Nietzsche seems to accept the commonsense definition. For instance, in the 1886 preface to $H H$ he writes, "Loneliness [Einsamkeit] encircles and embraces him [the free spirit], ever more threatening, suffocating, heart-tightening, that terrible goddess and mater saeva cupidinum" (HH P 3$){ }^{10}$ The free spirit is struck with feeling alone, which is characterized as "threatening," "suffocating," and "heart-tightening." All of these refer to states of pain. Indeed, when Zarathustra approaches his "ultimate loneliness," he cries that he must descend "deeper into pain than I ever descended, down to its blackest flood" ( $Z$ III: “The Wanderer"). For Nietzsche, loneliness signifies a painful psychological state caused by feeling alone.

Now the big question: Why does the demon offer the eternal recurrence to us when we are in our loneliest loneliness? The answer, I think, is not pretty: Nietzsche first wants us to fail the test-to recoil and "curse the demon" (GS 341). It should be obvious that facing the thought that our lives will recur "again and again" (GS 341) from a state of severe loneliness significantly amplifies the likelihood of eliciting a negative response. We are not presented the eternal recurrence in just any state of loneliness. If that were the case, we could imagine some individuals not being gripped by the demon's suggestion. Some might enjoy moments of loneliness, for instance, and thus the aversive effect of loneliness might be minimal. Instead, we are presented with the eternal recurrence in a very particular moment of our lives: our loneliest loneliness.

Loneliness is nearly always painful. And our loneliest loneliness must certainly be painful. Not only this, but profound loneliness is often 
associated with feelings of alienation, emptiness, unimportance, and worthlessness-perhaps even shame, guilt, and regret. ${ }^{11}$ The demon suggests that we imagine bearing the worst pain of feeling alone not just once, but "innumerable times again" (GS 341). Entertaining this thought, it seems to me, explains why Nietzsche calls the eternal recurrence the "heaviest weight" (GS 341). No one wants to imagine feeling his or her deepest, darkest loneliness again and again indefinitely. Genuinely embracing such a thought is simply crushing.

The fact that Nietzsche appears to want us to fail the test is supported by his understanding of our affective engagement with the world. R. Lanier Anderson helpfully explains that for Nietzsche affects involve a "stimulus object," or an object that activates an affect, and a "default behavioral response," or a typical behavior caused by a particular affect. ${ }^{12}$ Our hearing the demon deliver the thought of eternal recurrence is a striking stimulus object. What affective orientation does it activate? Given that we consider the test from a superlative state of loneliness, the test aims to produce the highest possible degree of the pain of feeling alone. This feeling would be immensely hard. And reviewing the entirety of our lives from such a state would likely highlight other times we were wrought with intensely negative feelings of isolation. Being in any maximally affective state should render us sensitive to similar states. If I were to imagine reliving my life again and again from a state of being enveloped in some extremely triumphant achievement, for instance, my attention would likely be drawn to similar feelings of success. Thinking about reliving our most extreme loneliness over and over again should therefore draw our attention to reliving other forms of painful isolation. Nietzsche asks, "Would you not throw yourself down and gnash your teeth and curse the demon who spoke thus?" (GS 341). Absolutely. Rejecting the test certainly appears to be the behavioral response Nietzsche expects us to have. But, I suggest, only initially.

The experiment is introduced in our loneliest loneliness because imagining our lives eternally recurring from that perspective should move us to overcome our loneliness after first cursing the demon. The painful thought of unending loneliness should push us to face the challenge of selftransformation. This is the behavioral response Nietzsche wants to provoke. He wants us to understand our psychological distress so that we transform ourselves. "Lonely one [Einsamer]," he says, "you are going the way to yourself," but, "You must wish to consume yourself in your own flame: how could you wish to become new unless you had first become ashes!" ( $Z$ I: "On the 
Way of the Creator"). Zarathustra proclaims that his "ultimate loneliness" involves going "down deeper than ever I descended-deeper into pain than I ever descended," and "It is out of the deepest depth that the highest must come to its height" ( $Z$ III: "The Wanderer"). ${ }^{13}$ Extreme loneliness enables us to embrace the eternal recurrence in the right spirit and work toward self-development.

One might worry that feeling deeply lonely is actually debilitating. Indeed, psychological studies have suggested that over time loneliness predicts increases of depressive symptomatology, ${ }^{14}$ and people who believe they face a future of social isolation tend to care about themselves less and less. ${ }^{15}$ But it has also been shown that loneliness signals to us that certain connections we strongly desire to forge require maintenance, ${ }^{16}$ and the drive to repair broken connections oftentimes outweighs debilitating inaction. ${ }^{17}$ Much could depend on our attitude toward being lonely, but loneliness appears to be a typically aversive psychological state that stimulates us to take action, specifically action that safeguards against feeling lonely. In this sense, loneliness can be a strong motivator.

Of course, many aversive psychological states, such as terror or hopelessness, can be motivating. However, I suggest that loneliness not only motivates self-transformation, but also puts us into a frame of mind to succeed at the task. The same cannot be said about other aversive psychological states, like terror or hopelessness. In fact, such states are often far too incapacitating to generate self-development, let alone enable success. The right kind of motivation is a first, crucial step, but motivation could come to nothing without a chance to succeed.

How do we develop a positive behavioral response to the eternal recurrence from a state of profound loneliness? If we take the test seriously as Nietzsche presents it, the test will not allow positive responses that concern sheer fantasy and otherworldly religion. Flights into fantasy, such as daydreams, involve voluntary creations of the imagination aimed at providing pleasure, which can help many avoid the pain of loneliness. But, according to Nietzsche, the eternal recurrence pertains to "this life as you now live it and have lived it" (GS 341), not some life we do not live but would like to live. The test also blocks escape by way of religion. Religions such as Christianity can provide the promise of lasting happiness and offer eternal companionship. ${ }^{18}$ But the eternal recurrence nullifies such consolation, since by hypothesis the test requires that we affirm or reject life only by assessing this world, where there is no 
lasting fulfillment and where we experience extreme distress. We need a response to loneliness that addresses these problems. ${ }^{19}$

I suggest that if we focus exclusively on being better disposed toward ourselves and this world, as Nietzsche says, then loneliness can provide conditions for what he would consider a successful response to the eternal recurrence. I want to point out three such conditions. These conditions are not meant to secure any necessary causal links between loneliness and self-transformation. For Nietzsche, nothing guarantees successful self-development. My argument is simply that loneliness presents a unique opportunity for such success. This should help explain the psychological setting of the eternal recurrence in GS 341 .

The first condition that loneliness supplies for what Nietzsche would consider a successful response to the eternal recurrence is a feeling of being disconnected from one's social environment, including intimate attachments, friends, family, and collective group identities. Feeling socially disconnected, according to Nietzsche, enables us to gain a unique perspective on social values. It allows us to take a critical stance on standardly recognized values, perhaps even question the value of those values. The causality will sometimes go in the other direction, such that being critical of social values leads to loneliness. And perhaps one's loneliest loneliness follows from critically engaging such values. Whatever the cause of loneliness, the point is that feeling personally isolated can indicate that one's values are incompatible with values commonly upheld and regulated by social relations. Social engagements often require acting in accordance with, or even supporting, values not fully our own, such that we feel out of place in regard to such values. Moreover, values that contribute to maintaining a harmonious social life are typically perceived to enjoy greater value than values endorsed by individuals regardless of social acceptance or utility. Loneliness can reveal the tension between values that we might authentically endorse and values that we might otherwise critically question or even reject. Loneliness can therefore provide significant insight into the values that we might want to embrace in order to become who we most desire to be. ${ }^{20}$

Feeling disconnected from the values that predominantly govern social life is fundamental for Nietzschean self-transformation. Importantly, such values are often closely associated with traditional moral systems. Nietzsche notes, "To endure the idea of the recurrence one needs: freedom from morality" (KSA 11:26[283], p. 224) ${ }^{21}$ Freedom from morality, at the very least, requires breaking from unreflective commitment to dominant structures of 
valuation. Nietzsche often points out that this break is typically motivated by a new understanding of existing value systems, specifically the revelation that traditional moral codes promote values that benefit the social order by downplaying individuality. "Morality," he remarks, "is herd-instinct in the individual" (GS 116). Feelings of loneliness, which can highlight the estrangement between one's own values and those that govern social life, can help make possible this recognition. Some individuals will find this recognition difficult to bear, of course, but finding the strength to embrace this disconnect has great positive potential. Loneliness can show us that we are in some important sense free from the grip of value systems that are disadvantageous to individual development.

The second feature of loneliness that can contribute to passing the eternal recurrence test is that lonely individuals actively distrust their social environment. Psychological studies have indicated that loneliness strongly increases attention to, and motivation to avoid, what are perceived to be the negative features of social life. ${ }^{22}$ Loneliness activates a heightened sensitivity to social dangers, which results from feeling uncertain about confiding in, depending on, or trusting others. On Nietzsche's account, immersion into social life can be dangerous in the sense that social entanglements often result in the kinds of dependencies and blind trusts that limit our capacity and ability to develop and express unique values. We therefore need to protect our self-development from being undermined by our social existence. Loneliness contributes to developing the psychological disposition that enables such protection.

This feature of loneliness plays an important role in the "lion" stage of Nietzsche's view of self-transformation, which is described in Zarathustra's "On the Three Metamorphoses." ${ }^{23}$ In the "loneliest [einsamsten] desert," Nietzsche says, the lion emerges to "conquer his freedom" and "be master in his own desert." Freedom and mastery require rejecting the dragon's "Thou Shalt" and affirming "I will." The dragon clearly represents traditional morality. According to Nietzsche, the lion "renounces" trust in, and dependence on, traditional moral values, which results in the "creation of freedom for oneself for new creation." In the loneliest desert, then, the lion creates better opportunities to gain authentic values, and this process relies on increased attention to features of social life that would damage self-development. ${ }^{24}$ Accordingly, Nietzsche notices that those who support traditional moral systems, especially those who consider themselves "good" and "just" from the perspective of traditional morality, find 
loneliness threatening. He writes, "[The good and the just] like to crucify those who invent their own virtue for themselves-they hate the lonely one" ( $Z$ I: "On the Way of the Creator"). Loneliness can arouse insight into how social life leads to the decline of individual good, which threatens social harmony. ${ }^{25}$

The third condition associated with loneliness that helps individuals affirm the eternal recurrence is that loneliness motivates self-interestedness. Although it seems that loneliness would induce us immediately to seek out company, rather than first caring for ourselves, research suggests the reverse. ${ }^{26}$ And, given the two conditions described above, this makes sense. We turn inward and attend to our own interests because loneliness not only involves feelings of separation, but also mistrust. When we feel our trust in social ties eroding, we tend to attempt repair from the inside out.

Importantly, Nietzsche thinks self-interestedness grounds self-transformation. His criticism of compassion (Mitleid) in GS makes the point clear. He asks, "Is it good for you to be above all else compassionate persons?" (GS 338). The answer is "no." The demands of reducing suffering disrupt self-development-"losing myself from my path" (GS 338). "Our own way," Nietzsche says, "is so hard and demanding and so far from love and gratitude of others that we are by no means reluctant to escape from it, from it and our ownmost conscience-and take refuge in the conscience of others" (GS 338). Loneliness can leave us feeling detached from the "love and gratitude of others," but rather than overcome loneliness by seeking care by others, or taking "refuge in the conscience of others," we must first care for ourselves. It might be hard to reject such refuge, but accepting the feeling that others have failed us can strengthen our resolve to focus on expressing our "ownmost conscience." Loneliness moves us to attend to ourselves, at least first and foremost, which is imperative for self-development.

Let me summarize the account so far. I have argued that imagining the eternal recurrence in a state of our loneliest loneliness provokes self-transformation because feeling disconnected from social life and distrustful toward common social connections moves us to seek out and embrace values that are truly our own. Nietzsche initiates the test when we are in an extreme state of isolation because he understands that our feelings of separation can inspire authenticity. But passing the test is clearly not easy. Nietzschean self-transformation is incredibly difficult. However, by having a proper understanding of the psychological setting of the test, we can begin to understand what enables us to overcome the hurdles we face. 
Before moving on, I want to be clear that none of what I have said entails that, on Nietzsche's account, loneliness reveals that we are nonsocial, or that Nietzschean self-development is a nonsocial project. Loneliness is not some ontological state of existing alone-it is the feeling of being alone, a feeling that transforms our understanding of social life. Our social existence is not something that can be rejected altogether. Nietzsche writes, for example, "These people who have fled inward for their freedom also have to live outwardly, become visible, let themselves be seen; they are united with mankind through countless ties of blood, residence, education, fatherland, chance, [and] the importunity of others" ( $S E$ 3, p. 139). Rejecting traditional values does not imply rejecting social values across the board, and endorsing authentic values does not imply endorsing nonsocial values. Nietzschean self-development does emphasize the individual, but there is no freeing the individual from social existence. Self-transformation helps us forge a better understanding of ourselves, which includes a better understanding of how we most want to connect to others, or how we might be authentic while maintaining our social connections. ${ }^{27}$

Now consider some objections. First, one might argue that it is inappropriate to appeal to the psychological studies that I have mentioned. Those studies draw general conclusions about ordinary individuals, whereas Nietzsche seems concerned only with higher individuals. It seems that the studies are irrelevant to Nietzsche's aims, and thus do no important work here.

My response is twofold. First, while Nietzsche certainly does focus on the importance of higher individuals, he also thinks everyone can and should attempt self-transformation. In an aphorism titled "Traffic with one's higher self," for instance, he says, "Everyone has his good days when he discovers his higher self; and true humanity demands that everyone be evaluated only in the light of this condition" (HH 624). Everyone has some relation to his or her higher self, and genuine humanity should be judged in terms of discovering that self. In another passage, he writes, "There is clearly no trick that enables us to turn a poor virtue into a rich and overflowing one, but we can surely reinterpret its poverty into a necessity, so that its sight no longer offends us and we no longer make reproachful faces at fate on its account" (GS 17). I see no reason to think that Nietzsche intends to limit the scope of this advice only to a select few. Indeed, from $U M$ to $E H$, Nietzsche consistently provides advice for how ordinary folk might transform themselves. Of course, such passages are usually not very provocative, 
and maybe that is why they are overlooked. But they are- undeniablyeverywhere. ${ }^{28}$ Nietzsche's famous proclamation "You should become who you are" (GS 270) is perfectly general. "The Three Metamorphoses" pertains to all agents. And anyone can feel "the heaviest weight," the eternal recurrence.

But-and this is second part of my response-not everyone can succeed in self-transformation, and Nietzsche thinks higher individuals have a better chance at success. He famously proclaims, "To 'give style' to one's character-a great and rare art! It is practiced by those who survey all the strengths and weaknesses that their nature has to offer and then fit them into an artistic plan until each appears as art and reason and even weaknesses delight the eye" (GS 290). Notice the universal scope: we can all give "style" to our characters. But the project requires "long practice and daily work," and Nietzsche reports that "it will be the strong and domineering natures who experience their most exquisite pleasure under such coercion," whereas "it is the weak characters with no power over themselves who hate the constraint of style" (GS 290). Weak-natured individuals certainly have a chance at successful self-transformation, but Nietzsche's description of the profound difference in affective responses between weak- and strong-natured individuals suggests that the latter have a better success rate. It is then likely that those who are able to affirm the eternal recurrence are those strong enough to overcome their loneliest loneliness, while weaker individuals have greater chances of failure. But we all have a shot, and the psychological studies I have cited help us understand how and why we might be motivated to succeed, which is clearly what Nietzsche wants.

A related worry is that it seems natural to say that our aversive feelings toward loneliness would move us to abandon the project of self-transformation, since such a project can itself cause terrible loneliness. Generating values that are uniquely our own could cause distressful isolation. Returning to "the herd" can ease that distress. Thus, loneliness seems to have the opposite effect of what I have presented here.

There is no doubt that some individuals could be motivated to avoid loneliness by rejecting self-transformation and running back to others. But this does not make the best sense of what we know empirically about loneliness, especially combined with the affective state of embracing the eternal recurrence test as Nietzsche imagines it. We are asked to review our lives from a maximal degree of loneliness. Even nonmaximally, though, loneliness reveals a separation from others, a distrust of others, and an 
incentive to look inward. The maximal state of loneliness, then, especially if one imagines that state repeating indefinitely, should undermine the motivation to embrace "the herd." Moreover, while aversive feelings toward loneliness might very well manifest themselves during the self-transformation process, undergoing that process should also manifest certain pleasures, in particular pleasures felt when we succeed at grasping values that express who we most desire to be. These pleasures have clear forward-moving motivational force. For this reason, those who find self-development pleasurable, such as higher individuals, have a strong chance of beating out aversive feelings after cursing the demon and embarking on the path toward self-development. Overall, then, the motivation to overcome our loneliest loneliness by transforming ourselves should effectively outweigh aversive feelings that arise during transformation.

One might also be worried that the psychological context of the eternal recurrence cuts us off not only from the herd, but also from friends who might empower self-development. Nietzsche's view of friendship, however, is not our ordinary conception. He writes, "Our faith in others betrays in what respect we would like to have faith in ourselves. Our longing for a friend is our betrayer" ( $Z$ I: "On the Friend"). Seeking friendship often counters self-reliance. But there are important exceptions. For Nietzsche, genuine friendship should advance mutual self-transformation. Such a project involves letting friends suffer so that they might become their best selves. He writes, "If one wants to have a friend one must also want to wage war for him: and to wage war, one must be capable of being an enemy. [...] Can you go close to your friend without going over to him?" ( $Z$ I: "On the Friend"). To "go over" to a friend is to provide blanket comfort in such a way that betrays the friend's ability to develop as an individual. Alternatively, being an "enemy" while being "close" involves choosing to deny comforts to friends at particular moments, with the aim of helping them undergo self-development. "Compassion for the friend," Nietzsche remarks, "should conceal itself under a hard shell" ( $Z$ I: "On the Friend"). Imagining the eternal recurrence is perhaps the most important moment for friends to withdraw explicit comfort, assuming the test does not already undermine the grounds of that relationship. Close friends should allow us to grapple with the terrifying thoughts of recurrence. Nietzsche therefore seems to think that the transformative power of the eternal recurrence is actually enhanced when someone is separated from close friends-and it may even be our friend's duty to ensure separation during such critical moments. 
Let us return to the issue about the desire to avoid loneliness. There is a common problem that bedevils our understanding the eternal recurrence as a practical thought experiment, which my reading solves. The problem is that Nietzsche's infamous "last man" might pass the test. The "last man" is someone who is perfectly self-satisfied-someone who is happy, comfortable, and lazy and sees no need to strive to achieve difficult goals, especially self-transformation. For these reasons, Nietzsche's "last man" is often considered the harbinger of nihilism. Unfortunately, it is easy to see the "last man" dismissing Nietzsche's demon with a complacent shrug and saying, "Sure, I would do this again forever. Why not?" It would be devastating for Nietzsche's account if the "last man" could easily and genuinely affirm the eternal recurrence. But launching the test from a state of profound loneliness prevents such a response. The "last man" would not want to entertain reliving painful isolation again and again indefinitely. The available reactions to such a thought can only be rejection that leads to failure or failure that invites change. Either way, smug self-satisfaction is unavailable. This crucial result requires paying close attention to the psychological context of the test.

Now consider other readings of the psychological setting of GS 341. Many commentators fail to notice the somber context altogether. But not all. Maudemarie Clark acknowledges the importance of the phrase "loneliest loneliness." On her account, our loneliest loneliness "suggests a situation of vulnerability to suggestions one would otherwise dismiss," and she identifies such vulnerability with "a situation in which critical powers are at a minimum." ${ }^{29}$ Clark is right about loneliness being a state of vulnerability, and it does seem that loneliness can reduce our critical powers in the sense that being vulnerable can block skepticism that might disarm the demon's thought and prevent it from being taken seriously. But loneliness does not minimize our critical awareness across the board. Empirical studies suggest that certain critical powers, specifically those that reveal various dangers involved with social life, are actually increased when one feels extremely lonely. Clark overlooks this positive feature of vulnerability-a feature that is vital for successfully achieving Nietzschean self-transformation.

Paul Loeb has offered the most extensive recent commentary on the eternal recurrence, so I would like to say something about his reading. Loeb views the eternal recurrence as a metaphysical view about the way the world is, rather than a practical thought experiment, and his interpretive goal is to explain how Nietzsche thinks we are able to discover the truth 
of eternal recurrence in order to motivate us to change our lives. Loeb is not trying to explain why Nietzsche thinks a thought experiment about the eternal recurrence can motivate self-development. Nonetheless, Loeb gives three different readings of "einsamste Einsamkeit," and even commentators who reject the metaphysical interpretation of the eternal recurrence could be tempted to embrace those readings. Though none of what follows directly challenges Loeb's work, I want to show, for those of us who prefer the thought-experiment reading, why none of Loeb's readings can both motivate and help us succeed at self-development.

I have already mentioned Loeb's first interpretation. He argues that "einsamste Einsamkeit" should be translated as "most solitary solitude," primarily because "solitude" captures what Nietzsche "commends as the best possible

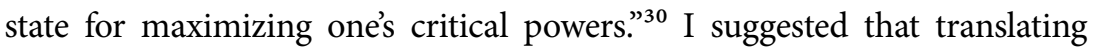
"Einsamkeit" as "solitude" in GS 341 leads to a significant difficulty: it fails to explain why self-development is motivated. For Nietzsche, self-transformation is motivated because we are terrified of what it would feel like to embrace the eternal recurrence from an extreme state of painful isolation-what it would feel like to endure lasting, profound loneliness, gritting one's teeth through feelings like alienation, unimportance, and the like, with no end in sight. Feeling confident in our critical abilities cannot be said to be nearly so motivating. Loeb writes that for Nietzsche solitude involves "isolating oneself from the common opinion in order to discover and bring to the surface one's own deepest instinctive wisdom." ${ }^{31}$ But such isolation puts the cart before the horse. It does not explain how feelings of isolation manifest the need for self-transformation in the first place. Loeb correctly characterizes Nietzschean solitude as an intentional state, but loneliness is typically a state into which we find ourselves helplessly thrown and needing to escape. ${ }^{32}$

Loeb's second reading of "einsamste Einsamkeit" falls short for similar reasons. "The most solitary solitude," Loeb says, "alludes to the poetic idea that everyone dies alone." ${ }^{33}$ But linking "Einsamkeit" to the idea that everyone dies alone requires translating "Einsamkeit" as "loneliness" rather than "solitude." The majority of us - though certainly not all—are scared of dying alone, not of being critically aware. And, given the right frame of mind, our fear of death can move us to achieve the best version of ourselves before we are gone. Again, the motivation to affirm the eternal recurrence relies on loneliness.

Loeb's final reading occurs in his most recent work. He claims that "the most solitary of solitudes in which I hear my demon's revelation alludes to Nietzsche's view that my conscious mind is the evolved psychological 
location for social communication." ${ }^{34}$ In intense solitude, Loeb suggests, we can hear our authentic voice speak to us, though the voice is unconscious. This interpretation pulls together disparate texts (namely, TI "Socrates" 4; BGE 6; GS 354) that connect the eternal recurrence to outside themes like representational consciousness and evolutionary psychology. As I see things, however, the message of $G S_{341}$ is clear in that very passage: Nietzsche believes that coming to grips with the demon's suggestion in a state of profound loneliness will be transformative. Loeb's account also implies that when we hear the demon we cannot consciously understand the need to undergo self-development. But GS 341 says nothing to this effect. In fact, the passage suggests the opposite. The task of becoming "well disposed" to ourselves and to life, such that we "long for nothing more fervently" than eternal recurrence, certainly appears to be a conscious affirmation. Nietzsche does think unconscious motives play a significant role in steering our lives, but an adequate response to the eternal recurrence is a reflective choice. ${ }^{35}$

With objections and alternative readings dispatched, let me conclude. I have attempted to explain the importance of the psychological context of GS 341 if we take the eternal recurrence to be a practical thought experiment meant to transform our lives. Hearing the demon in our loneliest loneliness not only encourages Nietzschean self-transformation, but also helps us succeed in this project, and empirical research can be marshalled to support this conclusion. The specific psychological context of GS 341 is therefore essential for understanding why and how the eternal recurrence is supposed to enable self-development.

\section{NOTES}

I would like to thank William Schroeder, Paul Loeb, the audience at the 2017 William J. Prior Conference at Santa Clara University, and anonymous reviewers at the Journal of Nietzsche Studies for providing excellent comments on earlier drafts of this article.

1. See, e.g., Alexander Nehamas, Nietzsche: Life as Literature (Cambridge, MA: Harvard University Press, 1985); Maudemarie Clark, Nietzsche on Truth and Philosophy (Cambridge: Cambridge University Press, 1990); Bernard Williams, "Introduction," in Friedrich Nietzsche, The Gay Science, trans. J. Nauckhoff (Cambridge: Cambridge University Press, 2001), vii-xxii; Robert Solomon, Living with Nietzsche: What the Great "Immoralist" Has to Teach Us (Oxford: Oxford University Press, 2003); Rex Welshon, The Philosophy of 
Nietzsche (Montreal: McGill-Queen's University Press, 2004); Graham Parkes, "Introduction," in Friedrich Nietzsche, Thus Spoke Zarathustra, trans. Graham Parkes (Oxford: Oxford University Press, 2005), ix-xxxiv; R. Lanier Anderson, "Nietzsche on Truth, Illusion, and Redemption," European Journal of Philosophy 13.2 (2005): 185-225; and Bernard Reginster, The Affirmation of Life (Cambridge, MA: Harvard University Press, 2006). For challenges to these readings, see Paul Loeb, The Death of Nietzsche's Zarathustra (Cambridge: Cambridge University Press, 2010), and "Eternal Recurrence," in The Oxford Handbook of Nietzsche, ed. Ken Gemes and John Richardson (Oxford: Oxford University Press, 2013), 645-74. I will not enter into this debate here (though see n. 19, below); other authors have discussed the issue at length. My intention is to offer something new for those who read the eternal recurrence as a practical thought experiment.

The epigraph to Clouther appears in We Were Flying to Chicago (New York: Black Balloon, 2014).

2. I use the following translations of Friedrich Nietzsche's published texts: Beyond Good and Evil, trans. Walter Kaufmann (New York: Vintage, 1989); Daybreak, ed. Maudemarie Clark and Brian Leiter, trans. R. J. Hollingdale (Cambridge: Cambridge University Press, 1997); Ecce Homo, trans. Walter Kaufmann (New York: Vintage, 1989); On the Genealogy of Morals, trans. Walter Kaufmann (New York: Vintage, 1989); The Gay Science, trans. Josefine Nauckoff (Cambridge: Cambridge University Press, 2001); Human, All Too Human, trans. R. J. Hollingdale (Cambridge: Cambridge University Press, 1996); Thus Spoke Zarathustra, in The Portable Nietzsche, ed. and trans. Walter Kaufmann (New York: Penguin, 1976), 121-439; "Schopenhauer as Educator," in Untimely Meditations, trans. R. J. Hollingdale (Cambridge: Cambridge University Press, 1997); Twilight of the Idols, trans. Duncan Large (Oxford: Oxford University Press, 1998).

3. Nietzsche also suggests that a successful affirmation of the eternal recurrence depends on experiencing one "tremendous moment" that would justify all things returning again. For a recent reading of this part of the passage that supports the metaphysical interpretation of the eternal recurrence, see Paul Loeb, "The Colossal Moment in Nietzsche's Gay Science 341," in The Nietzschean Mind, ed. Paul Katsafanas (New York: Routledge, 2018), 428-47. Those who read the passage as presenting the eternal recurrence as a practical thought experiment could read the "moment" as something we strive to achieve through self-development.

4. Clark's influential reading addresses the psychological setting of the eternal recurrence, which she reads as a practical thought experiment rather than a metaphysical thesis (Nietzsche on Truth and Philosophy, 251). I have two issues with Clark's reading. First, I argue below that recent psychological studies concerning loneliness challenge her understanding of it. Second, I find her account incomplete: it offers no explanation of how loneliness, in particular, is supposed to motivate and help us achieve self-transformation. My reading provides these details. For a treatment of Zarathustra's connection to loneliness in relation to the eternal recurrence considered as a metaphysical view in $Z$, see Karl Löwith, Nietzsche's Philosophy of 
the Eternal Recurrence of the Same, trans. J. Harvey Lomax (Berkeley: University of California Press, 1997), 29, 57-58, 65-68.

5. Loeb prefers this translation (Death of Nietzsche's Zarathustra, 20; "Eternal Recurrence," 649, 665). I challenge his reading near the end of the article.

6. For a recent commentator who recognizes the importance of this point, see Monika Langer, Nietzsche's Gay Science: Dancing Coherence (New York: Palgrave Macmillan, 2010), 210.

7. See, e.g., $B G E$ 225; $Z$ III: “The Wanderer." Nietzsche is not always consistent on this point. See $G S 370$ for a passage that complicates matters.

8. Note also that Nietzsche often regards self-reliance as an achievement, a project that requires a certain kind of motivation, namely, the motivation to undergo large-scale self-transformation. Such motivational force might very well come from the feeling that certain connections we would like to make to our best selves are absent or unachieved. This is not to say that self-reliance cannot be at all motivational. For instance, Nietzsche thinks self-reliance typically grounds the best forms of creativity. But self-reliance is often earned through difficult self-transformative work, which loneliness can motivate. Now turn to another issue. Loeb holds that Nietzsche distinguishes between solitude and loneliness when he writes, "Ein Anderes ist Verlassenheit, ein Anderes Einsamkeit" (Z III: “The Return Home"; see Loeb, "Eternal Recurrence," 665, and Death of Nietzsche's Zarathustra, 20). Loeb believes "Einsamkeit" should be translated as "solitude," while "Verlassenheit" should be "lonely" or "desolate." Nietzsche would then be saying, "To be lonely is one thing, to be solitary another." Along with both Kaufmann and Del Caro, however, I would translate "Verlassenheit" as "forsaken." In “The Return Home," Zarathustra's solitude presents to him various ways in which he has been cruelly abandoned by those who failed to understand his message. He is not simply lonely. I prefer the translation "To be forsaken is one thing, to be solitary another" (Del Caro, but not Kaufmann, offers this translation of "Verlassenheit" and "Einsamkeit"). Loneliness is not primarily at issue in the passage. Zarathustra's solitude speaks to him about ways he has been forsaken, and why returning to solitude is crucial for his self-development. I do think Nietzsche distinguishes between solitude and loneliness, as I explain in the article, but I do not believe this distinction turns on the passage Loeb cites.

9. This analysis helps us decide between "solitude" and "loneliness" when translating "Einsamkeit." On my account, "Einsamkeit" should be translated as "solitude" in contexts that showcase individual strength found by breaking away from the herd. For instance, Nietzsche writes, "But I need solitude [Einsamkeit]—which is to say, recovery, return to myself, the breath of a free, light, playful air" (EH "Wise" 8). The translation here is spot-on. "Einsamkeit" should be translated as "loneliness" in contexts that reveal the pain of being alone.

10. Here I have changed the translation from "solitude" to "loneliness", since this seems to better reflect Nietzsche's meaning. In another passage, Nietzsche connects his "ultimate loneliness [Einsamkeit]" to a "black sorrowful sea," a "nocturnal 
dismay," and going "deeper into pain than I ever descended, down into its blackest flood" ( $Z$ III: "The Wanderer"). Here, too, the translation is exactly right.

11. See Robert Weiss, Loneliness: The Experience of Emotional and Social Isolation (Cambridge, MA: MIT Press, 1975); John Cacioppo, Stephanie Cacioppo, and Dorret Boomsma, "Evolutionary Mechanisms for Loneliness," Cognition and Emotion 28.1 (2014): 3-21.

12. R. Lanier Anderson, "What Is a Nietzschean Self?", in Nietzsche, Naturalism, and Normativity, ed. Christopher Janaway and Simon Robertson (Oxford: Oxford University Press, 2012), 202-35, 218. See also Paul Katsafanas, The Nietzschean Self: Moral Psychology, Agency, and the Unconscious (Oxford: Oxford University Press, 2016), 104-6.

13. It is not a coincidence that the imagery of "gnashing" our teeth at the difficult thought of a past that cannot be changed also appears in $Z$ to explain and motivate redemption. Nietzsche says, “it was' - that is the name of the will's gnashing of teeth and most secret melancholy" (Z II: "On Redemption"), and "To redeem what is past in man and to re-create all 'it was' until the will says, 'Thus I willed it!' 'Thus I shall will it!' - that alone shall I call redemption" ( $Z$ III: "Old and New Tablets" 3). See also Loeb, "Eternal Recurrence," 649; Death of Nietzsche's Zarathustra, 37-38, $164-65$.

14. See John Cacioppo, Louise Hawkley, John Ernst, Mary Burleson, Gary Berntson, Bita Nouriani, and David Spiegel, "Loneliness within a Nomological Net: An Evolutionary Perspective," Journal of Research in Personality 40.6 (2006): 1054-85; R. L. Heikkinen and M. Kauppinen, "Depressive Symptoms in Late Life: A 10-Year Follow-Up," Archives of Gerontology and Geriatrics 38.3 (2004): 239-50; Meifen Wei, Daniel Russell, and Robyn Zakalik, "Adult Attachment, Social SelfEfficacy, Self-Disclosure, Loneliness, and Subsequent Depression for Freshman College Students: A Longitudinal Study," Journal of Counseling Psychology 45.4 (2005): 602-14.

15. See Roy Baumeister and C. Nathan DeWall, "The Inner Dimensions of Social Exclusion: Intelligent Thought and Self-Regulation among Rejected Persons," in The Social Outcast: Ostracism, Social Exclusion, Rejection, and Bullying, ed. Kipling Williams, Joseph Forgas, and William von Hippel (New York: Psychology Press, 2005), 53-76; W. Keith Campbell, Elizabeth Krusemark, Kara Dyckman, Amy Brunell, Jennifer McDowell, Jean Twenge, and Brett Clementz, "A Magnetoencephalography Investigation of Neural Correlates for Social Exclusion and Self-control," Social Neuroscience 1.2 (2006): 124-34.

16. See Cacioppo, Cacioppo, and Boomsma, "Evolutionary Mechanisms for Loneliness"; Ben Mijuskovic, Feeling Lonesome: The Philosophy and Psychology of Loneliness (Santa Barbara, CA: Praeger, 2015).

17. See Christopher Masi, Hsi-Yuan Chen, Louise Hawkley, and John Cacioppo, "A Meta-Analysis of Interventions to Reduce Loneliness," Personality and Social Psychology Review 15 (2011): 219-66. 
18. Note two things. First, what I have said here does not imply that those who embrace the Judeo-Christian religious tradition do not or cannot feel lonelyeven Jesus, for example, appears to experience deep loneliness in the Garden of Gethsemane. Nietzsche is simply blocking remedies to loneliness that turn on commitment to some nonempirical world. Second, one might think that loneliness, in particular, does not do enough work to block the religious "escape." If I think I am going to meet up with lost loved ones in heaven after I die, for instance, when I hear the thought experiment my loneliness should lead me to reject the story of the demon. After all, the demon's story is pretty fanciful! But Nietzsche never claims in $G S 341$ that the eternal recurrence presents a more plausible view than those offered by various religions. Providing that argument would be another matter altogether. I am only interested in understanding what kinds of reactions thinking about the eternal recurrence allows and disallows if we take the test seriously from the perspective of severe loneliness. The reactions must be constrained solely to "this life as you now live it and have lived it."

19. Someone sympathetic to reading the eternal recurrence as a metaphysical view about the way the world is might raise some objections here. If the eternal recurrence is not supposed to reflect the way the world is, one might contend, then it does not concern this life as we live it and have lived it. The eternal recurrence is just as otherworldly as heaven, for instance. Since Nietzsche thinks commitment to such otherworldly positions is life-denying, commitment to the eternal recurrence as a practical thought experiment rather than a metaphysical position seems life-denying. This suggests a related worry: the mere thought experiment of feeling our loneliest loneliness cannot genuinely motivate us to transform our lives for the better-after all, the demon is not real, the enduring loneliness is not real, and so on. It is all just a fantasy! I cannot answer all these concerns here. My primary aim is to offer the practical thought experiment reading something new and important. I will say, however, that the fact that the eternal recurrence does not reflect the way the world is does not imply that it does not concern this life as we live it and have lived it. I am perfectly capable of reflecting on this life as I have lived it and imagining those circumstances repeating. There is nothing otherworldly about my thought that the loneliest time in my life, for instance, the time when I lost the person I loved the most in this world, could be repeated. And that thought can be very motivating. When I recall how I felt after my close friend died-and I imagine this feeling over and over again-I can be deeply moved to transform my life for the better. For these reasons, at the very least, I am not swayed by the objections. My thanks to Paul Loeb for pushing me to be clear about these issues.

20. This could lead to interesting feedback loops, where, for example, loneliness could motivate critical awareness of social values, which could then reinforce intentional solitude from one's social environment; or critical awareness of social values could lead to loneliness, which could motivate further critical awareness and ground a similar form of solitude. 
21. Translated by Walter Kaufmann as The Will to Power \$106o. See also Z III: "On the Convalescent" 2, "On the Spirit of Gravity" 2, and "On Old and New Tablets" 2, 8, 26.

22. See Cacioppo, Cacioppo, and Boomsma, "Evolutionary Mechanisms for Loneliness"; John Cacioppo, Catherine Norris, Jean Decety, George Monteleone, and Howard Nusbaum, "In the Eye of the Beholder: Individual Differences in Perceived Social Isolation Predict Regional Brain Activation to Social Stimuli," Journal of Cognitive Neuroscience 21.1 (2009): 83-92; Steve Duck, Kris Pond, and Geoff Leatham, "Loneliness and the Evaluation of Relational Events," Journal of Social and Personal Relationships 11.2 (1994): 253-76.

23. See also $\mathrm{HH}_{3}$.

24. One might argue that the individual involved in the lion stage of self-transformation is coming to learn that solitude is something positive, and that this discovery reduces the distinctively lonely affect. But this is no objection. Nietzschean self-transformation aims at self-reliance. Nietzsche thinks the aversive state of loneliness motivates that process, and one positive effect is that such an aversive state enables us to pick out social dangers typically hidden from us, which works to ground self-reliance.

25. From the perspective of traditional moral systems, those who are lonely are considered "evil." Here "evil" simply indicates a break with traditional morality, which Nietzsche considers to be very important not only for self-development, but also for the development of an advanced social order (see GS 4 ). For an interesting take on how the demon in GS 341 might be considered "evil" in this important way, see Langer, Nietzsche's Gay Science, 209.

26. For research backing the view that loneliness motivates self-preservation, see Cacioppo, Cacioppo, and Boomsma, "Evolutionary Mechanisms for Loneliness."

27. This is a struggle we often witness in Zarathustra (see, e.g., Z II: "The Stillest Hour"; III: "On Involuntary Bliss"). For an informative account of how Nietzsche believes personal ethics are fundamentally relational, see Robert Guay, "Ethics as Social Philosophy: Nietzsche on Mutuality," The Journal of Nietzsche Studies 47.3 (2016): 351-83.

28. Just with respect to $H H$, for instance, see $H H_{1} \mathrm{I}_{164}, 290,292 ; A O M_{36}, 44,248$, 260, 329, 343, 345, 351, 355, 370, 401; WS 221, 329.

29. Clark, Nietzsche on Truth and Philosophy, 251.

30. Loeb, "Eternal Recurrence," 665; see also Death of Nietzsche's Zarathustra, 20.

31. Loeb, Death of Nietzsche's Zarathustra, 20.

32. Note three things: First, sometimes loneliness is an intentional state. For instance, the third book of $Z$ begins with Zarathustra knowing he must actively descend into loneliness eventually to face the eternal recurrence ( $Z$ III: "The Wanderer"). Second, for an interesting view that claims that loneliness is not caused by external factors, but is instead innate to the human experience, such that we often find ourselves helplessly thrown into feeling lonely, see Mijuskovic, Feeling Lonesome. Third, one might wonder whether passing the test does anything to 
remove loneliness. Does it get us a companion, for example, or a real friend? No. Passing the test helps us find and embrace authentic values, which can help us connect to people on our own terms, or help us be more authentically social. Does this do away with loneliness itself? Perhaps. For Nietzsche, it seems that we are most lonely when we do not have the knowledge, ability, or confidence to embody our own values while emerged in social life.

33. Loeb, "Eternal Recurrence," 649.

34. Loeb, "Colossal Moment," 442.

35. Loeb will likely say the unconscious is present in GS 341 because it follows GS 340. GS 340 concerns Socrates, who reports the influence of a demon ("daimonion"), or internal voice, and Loeb holds that Nietzsche understands Socrates' demon "as a kind of auditory hallucination stemming from his chaotic unconscious instincts" (Loeb, "Colossal Moment," 442; see TI "Socrates" 4). But there are difficulties with this reading. First, Socrates' demon never actually appears in GS 340 . The demon appears years later in TI "Socrates" 4. This suggests that the demon in GS 341 is Nietzsche's own. Moreover, in TI "Socrates" 4, Nietzsche never connects Socrates' demon to the unconscious-in fact, the unconscious is neither mentioned, nor does it seem implied. Nietzsche says Socrates' demon is associated with "auditory hallucinations," and auditory hallucinations need not be unconscious. Nietzsche writes that "Socrates' decadence" is signaled by "instincts" and judgments that are "logical." Instincts, for Nietzsche, are sometimes conscious and sometimes unconscious, and logical judgments certainly seem conscious. Nietzsche later says that everything about Socrates is "concealed, ulteriorly motivated, [and] subterranean," which could mean unconscious, but which straightforwardly only amounts to hidden. For all these reasons, I am not convinced that Nietzsche believes that the demon in GS 341 calls to our unconscious selves. My thanks to Scott LaBarge for conversations about Socrates that helped me make these points. 